\title{
A POSSIBILIDADE DE CONCESSÃO DE OFÍCIO DA TUTELA ANTECIPADA DIANTE DA AUSÊNCIA DE PREVISÃO EXPRESSA NO ART. 273 DO CPC
}

Karine Torres Furtado ${ }^{1}$

Resumo: O presente artigo examina a possibilidade do magistrado conceder a tutela antecipada de ofício, prevista no art. 273 do Código de Processo Civil, sem o requerimento expresso da parte. Verifica o referido instituto, apresentando o conceito legal, os fundamentos constitucionais e a possível colisão de direitos ou princípios fundamentais para a sua concessão. Investiga os fundamentos doutrinários da corrente que admite e daquela que não admite a respectiva outorga de ofício do adiantamento antecipado, tendo em vista a previsão expressa no art. 273 do Código de Processo Civil, exigindo o "requerimento da parte interessada" para a respectiva concessão da medida antecipatória.

Palavras-chave: Tutela Antecipada. Concessão da Tutela Antecipada de Ofício. Efetividade.

\section{INTRODUÇÃO}

O presente estudo verificará a possibilidade do magistrado conceder antecipadamente a tutela, prevista no art. 273,

1 Aluna da Escola Superior da Magistratura do Estado de Santa Catarina (ESMESC). Bacharel em Direito, Especialista em Direito Material e Processual Civil pelo CESUSC em convênio com a ESMESC. E-mail: karinetf@bol.com.br 
do Código de Processo $\mathrm{Civil}^{2}$, sem o requerimento expresso da parte.

A justificativa para a presente pesquisa é relevante porque apesar da expressa previsão normativa estabelecendo que a tutela só poderá ser antecipada quando houver o requerimento da parte, há uma corrente doutrinária afirmando que o juiz poderá conceder o adiantamento de ofício, mesmo diante da ausência de requerimento nesse sentido.

A tutela antecipada foi criada com o fim de distribuir o tempo no processo para que, ao final, a prestação jurisdicional, ainda que procedente, não se torne inócua. É uma forma de tornar efetiva a prestação da tutela jurisdicional, quando propicia o adiantamento tanto na hipótese do inciso I, do art. 273, do CPC (em casos de urgência), quanto na situação prevista no inciso II, do mesmo artigo (em casos de abuso de direito de defesa).

$\mathrm{O}$ art. 273, CPC, admite a concessão da tutela antecipada apenas quando a parte requerer. Por conta da expressão "requerimento da parte", parcela da doutrina pesquisada, o que parece ser a maioria, entende ser inadmissível a concessão de ofício da tutela antecipada, ou seja, sem requerimento expresso da parte. Porém, há quem entenda ser possível, diante de princípios constitucionais.

Pela interpretação literal do art. 273, do CPC, a concessão de ofício se revela inadmissível. Porém, se olharmos o processo pelo prisma constitucional, poderemos ter uma resposta positiva. Basicamente, a fundamentação para esse entendimento tem por base o direito fundamental a uma tutela efetiva em que o acesso ao judiciário, previsto no art. $5^{\circ}$, XXXV, da Constituição da República Federativa do Brasil ${ }^{3}$, não garante apenas o direito de propor uma ação ou a segurança de que o processo seja apenas devidamente legal. É mais do que isso, é preciso assegurar que a prestação da tutela jurisdicional seja célere e efetiva.

2 Doravante a citação do Código de Processo Civil será feita por meio da sigla CPC.

3 Doravante a citação da Constituição da República Federativa do Brasil será feita por meio da sigla CF ou referida apenas como Constituição Federal. 
Para a corrente que não admite a concessão de ofício, o magistrado não poderá conceder a antecipação que não foi solicitada, mesmo diante de casos urgentes e ainda que constate a presença de todos os requisitos legais autorizadores. A fundamentação para esse entendimento é a violação ao princípio da demanda, ao princípio dispositivo, ao princípio da adstrição do juiz ao pedido, além da questão da responsabilidade do juiz.

Assim, o presente artigo discorrerá sobre a constitucionalização do processo fazendo uma distinção entre princípios e regras, verificando o fundamento constitucional da tutela antecipada, fazendo uma abordagem acerca do possível conflito entre o princípio da efetividade e o princípio da segurança jurídica, examinando, por fim, a possibilidade da concessão de ofício da tutela antecipada e a sua possível violação aos princípios da demanda, do dispositivo, da adstrição do juiz ao pedido e a questão da responsabilidade pelo manejo indevido da tutela antecipada.

\section{CONSTITUCIONALIZAÇÃO DO PROCESSO}

Não se pode estudar qualquer ramo do direito sem chamar a atenção à Constituição Federal. Com o direito processual isso não seria diferente. Examinar o direito processual civil com base apenas no CPC é fechar os olhos para a moderna concepção das novas garantias processuais previstas na Constituição.

A doutrina moderna tem falado bastante em constitucionalização do processo. Isso significa, segundo Lopes (2007, p. 19), que a forma de estudar o direito processual deve ter em mente sempre a Constituição Federal, uma vez que esta, em vários dispositivos, consagra princípios e estabelece garantias aplicáveis ao processo.

O estudo do direito processual com base na Constituição Federal é o chamado Direito Processual Constitucional. Não se trata de novo ramo do direito, mas de um método de estudo. 
Neste sentido, é o ensinamento de Medina (2005, p. 3) quando afirma que o objetivo do Direito Processual Constitucional é sistematizar as regras e os princípios elencados na Constituição e relativos ao processo, não se tratando de um novo ramo do Direito, mas um método de estudo que pode agruparse tanto à Teoria Geral do Processo quanto constituir programa dos cursos de Direito.

A tutela constitucional do processo para Dinamarco (2008, p. 27) tem a definição e o objetivo de garantir o ajustamento dos institutos do direito processual e o seu funcionamento aos princípios que se originam da própria ordem constitucional.

Significa dizer que a ordem constitucional se preocupa em proteger o processo, assegurando-o de garantias e princípios, dos quais não se pode afastar nem o legislador infraconstitucional quando da elaboração das leis processuais, nem o operador jurídico quando da interpretação da lei.

Os princípios previstos na Constituição devem ser observados, segundo Oliveira $(2008$, p. 2), não apenas pelo legislador quando da confecção da norma, mas pelos juízes, litigantes e demais pessoas que atuam no meio jurisdicional, pois os atos a serem praticados devem ser livres de vícios para ser obtida a verdade e a entrega do bem jurídico tutelado a quem tem razão.

Mas não basta que o processo siga estritamente os desígnios constitucionais para que este cumpra o seu papel. $O$ processo deve ser observado, segundo Wambier, Almeida e Talamini (2005, p. 160), "sob o seu aspecto teleológico, ou seja, dos fins que lhe são próprios, especialmente quanto a função de resolver aquela parcela do conflito de interesses submetida ao poder estatal".

Assim, para garantir o respeito à dignidade da pessoa humana e a liberdade do cidadão é fundamental que o processo não seja apenas devidamente legal ou que seja garantido, amplamente, o acesso ao judiciário. É preciso muito mais do que isso. 
O cidadão que procura o Judiciário para ver resolvido o seu conflito de interesse merece receber uma prestação jurisdicional eficiente.

É o chamado princípio da efetividade da jurisdição ou do acesso à justiça, os quais são ponderados pelos princípios do devido processo legal e do contraditório e da ampla defesa. Embora todos sejam extraídos da ordem positiva, verifica-se que todos são considerados princípios jurídicos.

No que se refere à tutela antecipada é justamente aqui que reside o conflito entre os princípios constitucionais, quando da interpretação e aplicação do instituto. A antecipação de tutela garante a efetividade da jurisdição, mas não garante, rigorosamente ou pelo menos formalmente, o princípio do contraditório e da ampla defesa.

\subsection{Distinção entre princípios e regras}

A estrutura constitucional é formada por princípios e regras, por isso, é importante que se faça, neste momento, a distinção entre princípios e regras, uma vez que o que o exame do instituto processual da tutela antecipada ocorre, obrigatoriamente, sob o prisma constitucional.

$\operatorname{Vaz}$ (2002, p. 117) faz um comparativo entre as regras e os princípios, afirmando que a abstração e a generalidade dos princípios estão em um grau maior do que as regras; os princípios precisam das regras para que adquiram concretude, visto que são vagos e indeterminados; os princípios constituem fonte de elaboração e fundamento de validade das regras, estando em nível hierárquico superior; as regras têm conteúdo meramente funcional, pois estão voltadas para a disciplina de situações jurídicas específicas, enquanto que os princípios representam padrões de justiça; e finalmente, em caso de colisão de princípios, como estes possuem uma dimensão de peso, o princípio com peso relativo maior prevalecerá, sem que o de peso menor perca a sua validade. 
Portanto, enquanto as regras procuram regular uma situação específica, os princípios servem como ideais de justiça. E quando há uma situação de colisão, não haverá uma revogação entre eles, pois isso é fenômeno que só ocorre com as regras. $\mathrm{O}$ que ocorre é uma prevalência de um princípio sobre o outro, daquele que tem peso maior sobre o menor.

Neste sentido, ensina Bueno (2004, p. 6) asseverando que os princípios convivem uns com os outros mesmo quando suas definições colidem-se. Não há revogação entre eles porque isso é típico de regras jurídicas. O que ocorre é uma preponderância, ou seja, uma prevalência de uns sobre os outros. Diferentemente dos princípios, as regras colidem-se e revogam-se mutuamente.

Porém, é preciso ter cautela na aplicação dos princípios constitucionais, uma vez que a supervalorização dos princípios constitucionais poderá conduzir a preterição, por completo, da legislação processual ordinária.

Neste sentido, adverte Lopes (2004, p. 32), afirmando que é um risco supervalorizar os princípios constitucionais do processo visto que a exaltação do princípio contraditório, por exemplo, pode afetar a efetividade do processo. Da mesma forma que a proibição absoluta das provas ilícitas pode manter um inocente preso, assim como a interpretação literal do princípio da igualdade pode conduzir a um tratamento isonômico entre pessoas com deficiências daquelas que não a possuem.

No mesmo sentido é o ensinamento de Bedaque (2001, p. 50) asseverando que os princípios processuais podem tornar-se verdadeiros obstáculos aos escopos do processo, se forem enaltecidos inconsequentemente, sem levar em consideração a situação fática. Por isso, a relativização dos princípios se faz imprescindível para que seja possível obter uma prestação jurisdicional rápida e eficiente. Seu emprego não pode deixar de levar em conta o conflito, senão a constituição da estrutura processual será inadequada ao seu objeto. 
Se diante de um caso concreto houver a incidência de dois ou mais princípios constitucionais, ou seja, uma verdadeira colisão de princípios fundamentais, indicando saídas divergentes para o desfecho da demanda, a solução não será a revogação de um princípio pelo outro, como ocorre com as regras. A solução será fazer os dois princípios conviver harmonicamente.

Sobre o tema, explica Alexy (1999, p. 75), que as colisões de direitos fundamentais devem ser qualificadas como colisões de princípios e a solução para a referida colisão é a ponderação. Ponderação e princípios são as duas faces de um mesmo objeto. Quem realiza ponderações no direito, parte do pressuposto de que as normas têm a estrutura de princípios.

Como foi citada acima e sem a pretensão de esgotar o assunto, é oportuno verificar o que vem a ser a ponderação ou o princípio da proporcionalidade, como é mais conhecido.

Pelo princípio da proporcionalidade, Oliveira (2007, p. 325) explica que, diante de uma situação de fato, o intérprete deverá escolher uma técnica processual que consiga efetivar um dos princípios em colisão, da forma mais intensa possível, ocasionando ao outro a negativa da aplicação, com a menor intensidade possível.

Com as regras, o fenômeno ocorre diferentemente, visto que estas devem ser cumpridas ou não. Se forem válidas deve-se fazer apenas aquilo que ela mandou, nem além, nem aquém. Assim, a forma de aplicação das regras é a subsunção, enquanto que para os princípios utiliza-se a ponderação.

Neste sentido, afirma Alexy (1999, p. 75) que as regras são normas que devem ser sempre cumpridas ou não. Se ela é válida, deve ser feito exatamente aquilo o que ela ordenou, nem mais, nem menos. As regras são mandamentos para serem aplicadas no mundo fático e juridicamente possível. E a forma de aplicação das regras, ao contrário dos princípios, é a subsunção. 
O conflito entre regras soluciona-se, portanto, segundo Lopes (2004, p. 33) com "a exclusão de uma delas para permitir a aplicação da outra”.

Pelo exposto, pode-se afirmar que os princípios, por terem dimensão de peso, prevalecem um sobre o outro, mediante a aplicação da ponderação. No caso das regras, não se pode dizer o mesmo. A regra será aplicada ou não ao caso concreto mediante o fenômeno da subsunção.

E diante de uma colisão de princípios constitucionais, a solução será interpretar a Constituição sistematicamente, garantindo-se a interpretação que garanta a máxima efetividade, buscando o modo mais harmônico para garantir a sobrevivência de ambos os valores postos em debate. Isso tudo, mediante o uso da ponderação, para solucionar os falsos conflitos constitucionais existentes.

\section{ASPECTOS CONSTITUCIONAIS DA TUTELA ANTECIPADA}

O instituto da tutela antecipada surgiu no ordenamento jurídico por meio da Lei 8.952/94, que deu nova redação ao art. 273, do CPC, cujo caput passou a ter a seguinte redação “o juiz poderá, a requerimento da parte, antecipar, total ou parcialmente, os efeitos da tutela pretendida no pedido inicial, desde que, existindo prova inequívoca, se convença da verossimilhança da alegação e: I - haja fundado receio de dano irreparável ou de difícil reparação; ou II - fique caracterizado o abuso de direito de defesa ou o manifesto propósito protelatório do réu".

Eventualmente, como foi dito acima, poderá ocorrer uma colisão de normas, que poderá ser resolvida, pela subsunção se o conflito ocorrer entre regras, ou pela ponderação, se o conflito acontecer entre princípios.

No caso da tutela antecipada, dois princípios constitucionais ou direitos fundamentais são colocados em tensão: o da 
efetividade da tutela jurisdicional (art. $5^{\circ}, \mathrm{XXXV}$, da CF) e o da segurança jurídica (art. 5 ${ }^{\circ}$ LIV e LV, da CF).

Isso acontece por conta da ausência de sintonia entre o tempo e o processo e isso, segundo Dias (2007, p. 238), revela o tensionamento existente entre a segurança jurídica e a efetividade processual. Enquanto a efetividade privilegia institutos que procuram acelerar o processo ou, pelo menos, abrandar a demora decorrente da prestação jurisdicional, a segurança se preocupa com a manutenção de institutos que provocam, fundamentalmente, a prorrogação do andamento processual.

$\mathrm{O}$ princípio da efetividade pode ser visto no inciso XXXV, do art. $5^{\circ}$, da $\mathrm{CF}$, que assim prescreve "a lei não excluirá da apreciação do Poder Judiciário lesão ou ameaça a direito”. Tal princípio também é conhecido como direito de acesso à justiça ou acesso à ordem jurídica justa.

Segundo Watanabe (1996, p. 77), o referido inciso estampa ainda o princípio da inafastabilidade do controle jurisdicional, pois não visa somente o acesso formal ao Poder Judiciário, mas o acesso à ordem jurídica justa e o oferecimento de amparo efetivo e célere contra qualquer forma de denegação da justiça.

O acesso à justiça, segundo Albuquerque (2002, p. 239), pode ser compreendido como um acesso ao processo justo que prima por uma justiça imparcial e que permite a participação efetiva e adequada das partes no processo, garantindo a efetiva tutela dos direitos, pouco se importando com as diferentes posições sociais e as peculiaridades de cada situação de direito material. $\mathrm{O}$ acesso à justiça pode ser visto também como o acesso a informação e a orientação jurídica de modo célere e eficaz, sempre que algum cidadão precisar.

Já o princípio da segurança jurídica pode ser conferido no inciso LIV, do art. 5 , da CF, que assim está redigido "ninguém será privado da liberdade ou de seus bens sem o devido processo legal", e no inciso LV, do mesmo artigo "aos litigantes, em processo judicial ou administrativo, e aos acusados em geral 
são assegurados o contraditório e ampla defesa, com os meios e recursos a ela inerentes".

Por conta deste princípio, é que a concessão da tutela antecipada, sem a oitiva do réu, deverá ser usada com cautela. É preciso verificar a real presença dos requisitos previstos em lei, autorizadores de seu deferimento, uma vez que a parte tem como garantia constitucional o princípio do contraditório e da ampla defesa.

Neste sentido, entende Figueira Jr. (2007, p. 134) para quem o instituto da tutela antecipada, em síntese, viola radicalmente o princípio do contraditório, especialmente quando é concedido sem a oitiva da parte adversa. Isso comprova que se trata de um instituto de natureza excepcional devendo ser tomada pelo juiz, de forma criteriosa, se e quando devidamente comprovados os requisitos genéricos e específicos.

É importante anotar ainda que os dois princípios derivam diretamente do texto constitucional, razão pela qual, não há que se falar em hierarquia entre ambos.

Neste sentido, é a orientação de Orione Neto (2002, p. 123) quando afirma que os dois princípios devem ser tratados de forma idêntica por parte do legislador e do juiz, visto que, no âmbito normativo, não há hierarquia entre o princípio da efetividade e o da segurança jurídica, justamente, porque ambos derivam da Constituição Federal.

E por se tratarem de princípios constitucionais ligados intimamente a concessão da tutela antecipada, é conveniente falar brevemente sobre eles, o que será feito oportunamente nos itens a seguir.

\subsection{Direitos fundamentais dos litigantes: a efeti- vidade da jurisdição}

Como se disse acima, o princípio da efetividade pode ser encontrado no inciso XXXV, do art. $5^{\circ}$, da CF, o qual exige que a lei não exclua de apreciação do Poder Judiciário qualquer lesão 
ou ameaça a direito. $\mathrm{O}$ referido princípio também é conhecido como direito de acesso à justiça ou acesso à ordem jurídica justa. É importante salientar que o acesso à justiça não deve ser visto apenas como um direito formal de ir a juízo, independente das condições sociais ou jurídicas em que o indivíduo se encontra. A tônica agora é ver o processo pelas suas implicações econômicas e sociais.

Neste sentido, ensina Albuquerque (2002, p. 238) afirmando que as desigualdades econômicas e sociais devem ser uma das metas a serem alcançadas pelo Estado, não devendo o pensamento do processualista de hoje ser igual ao dos liberais burgueses dos séculos XVIII e XIX, em que o direito à jurisdição expressava apenas o direito formal de contestar uma ação ou, em outras palavras, apenas o direito de comparecer em juízo, pouco importando se a parte estava capacitada ou bem representada, ou ainda se esta tinha condições de usufruir este direito.

Assim, pelo princípio constitucional da efetividade exige-se do processualista não só a resolução das questões que estão dentro do processo, mas as causas e os reflexos que esses problemas refletirão além do processo.

A tutela antecipada é um instituto que mitigou o processo tradicional, que primava pelo procedimento ordinário de cognição plena e exauriente, o qual priorizava a segurança jurídica em detrimento da efetividade, prestigiando, por conseqüência, muito mais a posição ocupada pelo réu no processo.

Neste sentido, são os ensinamentos de Marinoni (2002, p. 13), afirmando que no momento em que a doutrina clássica estabeleceu o procedimento ordinário, entendido aquele de cognição plena e exauriente, suprimiu os procedimentos materialmente sumários, especialmente aqueles de cognição parcial, privilegiando o fator segurança em prejuízo da efetividade.

Há várias formas de alcançar a efetividade do processo. Bueno (2004, p. 10) afirma que para isso é preciso buscar pela efetividade da jurisdição e por um processo civil de resultados, 
como por exemplo, a tutela específica dos arts. 461 e 461-A, do CPC, fortalecendo os poderes do juiz na busca dessa efetividade e prestigiando os métodos de agilização da prestação jurisdicional, como por exemplo, o julgamento antecipado da lide, a antecipação da tutela, a execução por títulos extrajudiciais, o processo monitório, entre outros.

Assim, pode-se afirmar que a antecipação de tutela, ao lado de outros institutos, é uma forma de tornar efetiva a prestação da tutela jurisdicional, tendo ainda como escopo fundamental a incumbência de dividir o ônus do tempo no processo.

Neste sentido, Marinoni (2006, p. 31) afirma que a tutela antecipada prevista no art. 273, do CPC, é o resultado da visão de uma doutrina processual moderna, que foi hábil em perceber que o procedimento deve ter um método de repartição do ônus do tempo no processo. Assim, a tutela antecipada constitui uma técnica muito importante para a concretização da efetividade no processo, não só porque propicia a efetivação urgente dos direitos previstos no inciso I, do art. 273, mas também porque admite o adiantamento em casos de abuso do direito $(273$, II), assim como no caso de parcela incontroversa da demanda (art. 273, \$6 $6^{\circ}$.

Atualmente, as funções do processo de conhecimento se confundem com as funções do processo de execução. É o que se costuma chamar de processo sincrético. Tais fenômenos, que eram características apenas de procedimentos especiais, passaram a ser generalizados para todo tipo de procedimento com a inserção, no sistema processual, da tutela antecipada. Esse sincretismo é interessante porque visa precisamente aperfeiçoar a prestação da tutela jurisdicional, reduzindo o tempo do processo.

Neste sentido, Bueno (2004, p. 12) afirma que atualmente, com o fim de buscar e alcançar a efetividade da jurisdição, admite-se que, num mesmo processo, as diversas atividades jurisdicionais apresentem-se conjuntamente (sincretismo), otimizando, assim, a prestação jurisdicional. 
E se antes a classificação do sistema de proteção de tutelas se dava na forma declarativa, constitutiva e executiva, modernamente, a consideração é feita também pelos resultados esperados no processo, ou seja, os efeitos que este pode refletir no direito material.

Neste sentido, aponta Silva (2007, p. 8), que a tendência moderna encaminha-se no sentido de dar maior importância à efetividade dos direitos adotados pela ordem jurídica, em detrimento da segurança obtida com o processo ordinário de cognição plena.

É importante salientar que a efetividade do processo não se confunde com a celeridade. Há situações em que um processo é movimentado de modo muito rápido, mas pelo descuido ou falta de cautela na observação de princípios processuais indispensáveis, desencadeiam uma série de problemas futuros para as partes.

É a advertência feita por Lopes (2004, p. 34) quando afirma que a efetividade não pode ser confundida com a celeridade, embora esta seja um dos aspectos fundamentais daquela. Isso quer dizer que nem sempre um processo célere será necessariamente um processo efetivo se prejudicar as garantias constitucionais. E o referido autor dá um exemplo, referindo-se a uma ação de grande complexidade, em que sejam exigidos conhecimentos periciais contábeis e que o juiz, após indeferir a perícia, tenha julgado antecipadamente a lide. Neste caso, o julgamento seria precipitado e não antecipado e, julgamento precipitado, evidentemente, não garante a efetividade da jurisdição.

A efetividade é prevista constitucionalmente, portanto, é imprescindivel que ela sirva de orientação na condução do processo. Porém, para ser efetivo é preciso cuidar para não ferir outros valores previstos constitucionalmente, a fim de garantir a presença de um processo justo.

E os princípios que intensificam o processo justo devem ser privilegiados, conforme afirma Aleixo (2007, p. 429), uma 
vez que o juiz, na condução do processo e com respaldo constitucional, tem poderes para moldar o procedimento às particularidades do caso concreto, como forma de melhor proteger o direito material. Assim, sempre que o juiz considerar relevante a modificação do procedimento original ou de que um novo meio procedimental será adotado para preencher o déficit legal, é indispensável, em obediência aos princípios da lealdade e da cooperação, que seja feito um anúncio prévio às partes, bem como a indicação dos motivos que levaram a sua adoção. Isso tudo em homenagem ao contraditório para que o comportamento das partes estejam de acordo com o novo procedimento vigorante.

Pelo visto, a máxima da efetividade é condição indispensável para perfeito atendimento ao princípio do acesso ao judiciário. Porém, tal efetividade não deve ferir garantias mínimas constitucionais, sob pena de inocuidade do instituto.

Assim, para dar maior celeridade e efetividade ao processo, foi criado o instituto da tutela antecipada, que numa cognição sumária, possibilita ao juiz a antecipação dos efeitos práticos da futura decisão, desde que exista prova inequívoca que o convença da verossimilhança da alegação.

Por fim, a efetividade do processo deve ser entendida como a forma de reconhecer o processo como um instrumento para a concretização do direito material. Não se trata de um extermínio de um princípio sobre outro. Houve apenas uma prevalência do princípio da efetividade da jurisdição sobre o contraditório e a ampla defesa.

\subsection{Direitos fundamentais dos litigantes: a segu- rança jurídica}

Em regra, a tutela jurisdicional será prestada pelo Estado em processo no qual seja garantida a igualdade de condições, oportunizando-se o oferecimento de alegações em face do litigante adversário, produzindo-se ou impugnando-se as provas confeccionadas. 
Para garantir a segurança jurídica, a Constituição Federal oferece vários mecanismos aos litigantes, como os princípios do contraditório, da ampla defesa, do juiz natural, entre outros.

Basicamente, isso reflete o que dispõe o texto constitucional no inciso LIV, do art. $5^{\circ}$ da CF, que assim está redigido "ninguém será privado da liberdade ou de seus bens sem o devido processo legal" e no inciso LV, do art. $5^{\circ}$, quando declara que "aos litigantes em processo judicial ou administrativo, e aos acusados em geral são assegurados o contraditório e a ampla defesa, com os meios e recursos a ela inerentes". É o princípio do devido processo legal que possui como desdobramento o contraditório e a ampla defesa.

Pelo princípio do devido processo legal pode-se dizer, conforme Dias (1999, p. 14), que ninguém será privado de sua liberdade ou de seus bens sem a garantia prévia de um processo, em que sejam respeitados os princípios processuais ditados no ordenamento constitucional.

Mas de nada adianta priorizar um processo devidamente legal se este não for efetivo. Seria inócua uma decisão justa se esta não for dada a tempo de resolver o conflito. Isso quer dizer que o réu nem sempre será ouvido antes da prática de um ato processual, porque é perfeitamente possível a concessão de liminar sem a oitiva da parte contrária quando a citação do réu, por exemplo, puder tornar ineficaz a medida ou quando a urgência determinar a concessão da tutela antecipada pretendida.

Porém, é importante advertir que o réu não estará completamente desamparado na relação processual. As garantias do contraditório e da ampla defesa do réu no devido processo legal foram apenas diferidas (e não esquecidas ou aniquiladas) para momento posterior do processo, enquanto o magistrado analisa o caso concreto para fazer incidir o princípio da efetividade da jurisdição.

Neste sentido, é o ensinamento de Vaz (2002, p. 123) afirmando que já é consagrado na doutrina e na jurisprudência, o 
entendimento de que as medidas liminares concedidas, sem a oitiva da parte contrária, não fere o princípio do contraditório. Segundo o referido autor, o princípio contraditório manifestase em duas premissas: a que o considera segundo a ótica da decisão definitiva (de mérito) e a que o considera sob o ponto de vista da decisão provisória. Na decisão definitiva, o contraditório deve ser sempre observado a priori. E na decisão provisória, o contraditório poderá ser realizado a posteriori.

Portanto, se a decisão tiver de ser pronunciada, em caráter definitivo, o contraditório deverá ser instituído sempre antes da respectiva decisão. Mas, se a decisão for proferida em caráter provisório, como é o caso da tutela antecipada, o contraditório poderá ser oportunizado em momento posterior à prolação da respectiva decisão. Desta forma, tanto o princípio da efetividade quanto o da segurança estarão preservados, visto ambos não foram dispensados de aplicação.

A antecipação da tutela, portanto, não ofende o princípio constitucional do contraditório, visto que este apenas fica diferido para momento posterior da instrução. Prova disso é que o processo prossegue para posterior julgamento, podendo a antecipação de tutela ser confirmada ou não na sentença.

É importante advertir que a não confirmação da tutela antecipada poderá gerar responsabilidade daquele que se beneficiou do adiantamento, conforme preconiza o $\$ 3^{\circ}$, do art. 273, do CPC. A questão da responsabilidade será tratada oportunamente em item específico.

Como foi dito, é admissível a concessão da tutela antecipada sem a oitiva da parte contrária, sem que isso ofenda o princípio do contraditório. Porém, verifica-se que esse entendimento não é tão pacífico quanto possa parecer. Isso porque há três correntes doutrinárias que enfrentam a questão de forma diferente.

Há aqueles que não admitem a concessão da tutela antecipada sem a oitiva da parte contrária em hipótese alguma; há, 
ainda, aqueles que a admitem apenas na hipótese do inciso I, do art. 273, do CPC; e, finalmente, aqueles que entendem ser possível a concessão liminar, sem o contraditório, em ambos os incisos do art. 273, do CPC.

A primeira corrente é muito bem representada por Passos (2004, p. 30), o qual entende que toda a antecipação de tutela concedida antes da citação é inadmissível e inconstitucional. A prova produzida unilateralmente pelo autor, sem o crivo do contraditório, é imprestável e não é suficiente para o convencimento do juiz. Se a produção da prova é unilateral (ônus da prova), o interesse na prova é das duas partes, ou seja, a prova é o juízo feito pelo juiz acerca das versões dadas pelos demandantes e, se não houver essa bilateralidade, haverá mera alegação. Nessa situação, poder-se-ia falar em plausibilidade do direito, o que autorizaria apenas a medida de cunho cautelar, e desde que verificada a necessidade de contra-cautela como forma de preservar o princípio da igualdade.

A segunda corrente entende que a antecipação liminar, sem oportunidade para o contraditório, só pode ocorrer na antecipação assecuratória, na qual existe o perigo de dano, não podendo ocorrer na antecipação punitiva, a qual pressupõe a prática de atos pelo réu de forma a perturbar o curso do processo.

Neste sentido, é o entendimento de Didier Jr., Oliveira e Braga (2007, p. 558), quando afirmam que a concessão liminar, antes da oitiva do réu, somente poderá ser deferida na antecipação assecuratória, isso porque, não há razão para o diferimento do princípio contraditório quando não houver risco da ocorrência de dano antes da citação do réu. No caso da antecipação punitiva, é complicado visualizar a prática de atos pelo réu para atrapalhar o processo antes de sua efetiva participação na causa. Porém, pode-se imaginar a situação em que o réu se esquiva para não receber a citação.

Na mesma direção, assevera Rodrigues (2008, p. 671) que, desde o pedido inicial a tutela antecipada pode ser concedida, 
quando a relação processual ainda é linear (autor-juiz), destarte, inaudita altera parte. A mesma solução não se aplica a situação prevista no inciso II, do art. 273, do CPC, tendo que vista que, para a conformação do abuso do direito de defesa, é imprescindível que o réu esteja participando do processo.

E por fim, há ainda a corrente doutrinária que entende ser possível a antecipação da tutela, sem oportunidade para o contraditório, inclusive, na hipótese prevista no art. 273, II, do CPC.

Neste sentido, é o entendimento de Nery Junior e Rosa Nery (2002, p. 618) afirmando que é cabível a concessão de liminar com base no inciso II, do art. 273, do CPC, mesmo quando o abuso do direito de defesa é verificado fora do processo. Isso pode ocorrer, por exemplo, quando há prova idônea de que o réu, notificado várias vezes para cumprir o compromisso, limitou-se a apresentar evasivas, não adimplindo a obrigação.

Comunga deste mesmo entendimento Bruschi (2008, p. 432) para quem a tutela será adiantada, em regra, após a resposta do réu, quando ocorrerem situações que impeçam a habitual movimentação do processo. Em regra, porque para o referido autor existe, inclusive, nessa hipótese, a possibilidade de concessão do adiantamento antes mesmo da citação do réu, citando Teresa Arruda Alvim Wambier e Nelson Nery Junior.

Para essa última corrente doutrinária, constata-se que a antecipação de tutela com fundamento no inciso II, do art. 273, do CPC, pode ocorrer, liminarmente, sem a citação do réu e mesmo sem a resposta, uma vez que o abuso do direito de defesa já pode estar configurado fora do processo, antes mesmo do ajuizamento da ação.

Por todo o exposto, verifica-se que há uma prevalência do direito fundamental da efetividade sobre o da segurança jurídica. Porém, o princípio do contraditório não foi aniquilado com a concessão da tutela antecipada sem a participação da 
parte adversa. A sua intervenção ficou apenas postergada para momento posterior do processo.

\section{A POSSIBILIDADE DE CONCESSÃO DA TUTELA ANTECIPADA SEM REQUERIMENTO EXPRESSO DA PARTE}

$\mathrm{O}$ acesso ao Poder Judiciário está consagrado no art. 5, XXXV, da Constituição da República Federativa do Brasil, consignando que nenhuma lei excluirá da apreciação do Poder Judiciário lesão ou ameaça de direito. Tal dispositivo traduz o princípio da efetividade do processo, o qual também é referido como o direito de acesso à justiça ou acesso à ordem jurídica justa, e ainda como o princípio da inafastabilidade do controle jurisdicional.

O que se busca, por meio do referido princípio, é o acesso a ordem jurídica justa e efetiva, afastando qualquer forma de ameaça ou lesão ao direito, e não apenas o acesso formal ao Poder Judiciário.

A pretensão resistida é levada ao Poder Judiciário por meio da ação. A partir daí, aquele deverá resolver o conflito de interesses substituindo as partes na entrega da prestação jurisdicional, observando, para tanto o princípio do devido processo legal, previsto constitucionalmente, no art. $5^{\circ}$, LIV, da CF.

$\mathrm{O}$ art. 273, caput, do CPC dispõe que "o juiz poderá, a requerimento da parte, antecipar, total ou parcialmente, os efeitos da tutela pretendida no pedido inicial, desde que, existindo prova inequívoca, se convença da verossimilhança da alegação". O referido dispositivo consagra a tutela antecipada, tratada anteriormente, aplicável genericamente aos processos de rito ordinário ou sumário.

Pelo citado artigo, verifica-se que o juiz poderá conceder, total ou parcialmente, os efeitos da tutela pretendida no pedido. Ressalte-se que o legislador exigiu, para a concessão da tutela antecipada, o requerimento da parte. 
Por conta da expressão "requerimento da parte", uma boa parcela da doutrina pesquisada, o que parece ser a maioria, entende ser inadmissível a concessão de ofício da tutela antecipada, ou seja, sem requerimento expresso da parte. Porém, há quem entenda ser possível, diante de princípios constitucionais.

Algumas fundamentações para aqueles que não admitem a concessão da tutela antecipada de ofício embasam seu entendimento no princípio da demanda ou iniciativa da parte, no princípio dispositivo, no princípio da adstrição do juiz ao pedido, além da questão da responsabilidade do juiz.

As duas correntes possuem as suas razões e justificativas para fundamentar a possibilidade ou não de concessão da tutela antecipada de ofício. É o que nos preocuparemos em falar a seguir.

\subsection{A possível violação ao princípio da demanda.}

O princípio da demanda tem previsão legislativa nos arts. $2^{\circ}$ e 262, do CPC. Assim dispõe o art. 20 "nenhum juiz prestará a tutela jurisdicional senão quando a parte e ou o interessado a requerer, nos casos e formas legais”. Já o art. 262 tem a seguinte redação "o processo civil começa por iniciativa da parte, mas se desenvolve por impulso oficial".

A corrente que não admite a concessão da tutela de ofício indica que a medida infringe o princípio da demanda, uma vez que este princípio autoriza o magistrado a se manifestar apenas quando o interessado a requerer.

Neste sentido, é o entendimento de Alvim (2003, p. 40) afirmando que a tutela antecipada concedida de ofício viola o princípio da demanda e, ao contrário do que ocorre com a providência cautelar que admite, em determinadas ocasiões, a medida de ofício, com base no art. 797 do CPC, a tutela antecipada só pode ser outorgada mediante o requerimento da parte. E ainda assim, apenas as cautelares indicadas no art. 797 podem ser deferidas de ofício. Já as cautelares previstas no art. 798 
dependem de requerimento como qualquer provimento antecipatório. Isso não poderia ser diferente, visto que a reforma manteve-se fiel aos princípios basilares do processo civil, como os princípios do dispositivo e da demanda.

No mesmo sentido Dinamarco (2001, p. 149), para quem o deferimento da tutela antecipada exige o requerimento da parte, uma vez que o nosso sistema processual aderiu expressamente ao princípio da demanda (art. 20 e 262, do CPC), indicando que o interessado pelo acolhimento da pretensão insatisfeita é quem deve verificar a conveniência e a oportunidade de requerer os meios para a satisfação.

Ainda sobre o princípio da demanda, lecionam Cintra, Grinover e Dinamarco (2007, p. 63), afirmando que a ação é o direito ou o poder de movimentar os órgãos jurisdicionais, com o fim de satisfazer uma pretensão, sendo a jurisdição inerte. $\mathrm{O}$ princípio de demanda indica que a parte deve iniciar o exercício da função jurisdicional, mediante a provocação do interessado.

Fundamental no direito processual civil, o princípio da demanda informa que o juiz não pode iniciar a solução dos conflitos, cabendo às partes, se assim o desejarem, levar ao Poder Judiciário para que este, em substituição, os solucione. $\mathrm{O}$ Poder Judiciário deve manifestar-se apenas quando provocado.

É importante salientar que a inércia do poder jurisdicional não pode ser confundida com o conteúdo do princípio da demanda. O Poder Judiciário é inerte por conta do princípio da inércia da jurisdição. Embora com conteúdo bastante similares, os dois princípios possuem óticas diferentes de análise.

Neste sentido, é o ensinamento de Portanova (2001, p. 70), quando afirma que há semelhança entre o princípio da inércia e o da demanda, distanciando-se, apenas, sob o prisma de análise. A inércia pode ser ambientada pelo aspecto passivo, ou seja, é a jurisdição que espera passivamente a provocação da parte por meio da demanda. Pelo aspecto ativo, é a parte quem mobiliza o poder jurisdicional, que por sua vez, é inerte. 
Superada a conceituação sobre o princípio da demanda e sua diferenciação com o princípio da inércia, é imprescindível colacionar a consideração feita pela doutrina que afirma que a concessão de ofício não afronta o princípio da demanda.

Segundo Pereira Filho (2004, p. 38), o "princípio da demanda exige a iniciativa da parte e, uma vez movimentada a jurisdição, a preocupação passa a ser com os princípios dispositivo, impulso oficial, congruência ou adstrição ou vinculação do juízo ao pedido da parte”.

$\mathrm{Na}$ mesma direção entende Albuquerque (2000, p. 55) afirmando que há respeito ao princípio da demanda se houver um pedido implícito da parte. $\mathrm{O}$ princípio da demanda estará sendo respeitado se for razoável calcular que se esta teria expressamente requerido se tivesse condições de o fazer.

Pelo exposto, é plausível admitir que o juiz não pode iniciar de ofício uma demanda, mas, uma vez provocada a manifestação do Poder Judiciário pelo interessado e, respeitados todos os requisitos legais para o ajuizamento de uma ação, o processo se movimenta por impulso oficial.

O princípio do impulso oficial, segundo Cintra, Grinover e Dinamarco (2007, p. 350), traduz a idéia de que incumbe ao magistrado o dever de, uma vez instaurado o processo, movimentá-lo, de fase em fase, até o completo exaurimento da prestação da tutela jurisdicional.

É importante ainda não confundir o princípio da demanda com o princípio dispositivo. A distinção entre os dois princípios é feita por Pereira Filho (2004, p. 40), o qual afirma que pelo princípio da demanda o juiz não pode, de ofício, dar início a uma relação jurídica processual, e pelo princípio dispositivo é facultado às partes escolherem a prática de certos atos processuais já com o processo em andamento.

Enquanto o da demanda é imprescindível para a parte movimentar a jurisdição, o dispositivo diz respeito ao poder de disposição que as partes tem em relação ao processo, 
concernente aos fatos, ao pedido e mesmo a produção probatória.

Aliás, outra alegação da doutrina que não admite a concessão de ofício seria a afronta ao princípio dispositivo, o qual será tratado no item a seguir.

\subsection{A possível violação ao princípio dispositivo}

A violação ao princípio dispositivo é mais uma razão para a não concessão de ofício da tutela antecipada para a corrente que não admite o citado procedimento.

Assim é o posicionamento de Machado (1998, p. 523) quando assevera que por conta do contido no caput, do art. 273, do CPC, ficou instituída, expressamente, a vedação à concessão da medida de ofício e confirmado o princípio da iniciativa da parte ou dispositivo na esfera antecipatória. Tais princípios resguardam à parte, simultaneamente, decidir sobre o tempo, o local e a maneira que mais lhe agrade para solicitar a providência jurisdicional, bem como garante a equidistância e a imparcialidade do juiz, o que, acumulado ao princípio do contraditório, compõe parte da essência do devido processo legal.

No mesmo sentido, é o entendimento de Lopes (2007, p. 96) afirmando que o instituto da tutela antecipada é de interesse público e foi inserido no $\mathrm{CPC}$ com a finalidade de favorecer o autor, cujo direito se mostre plausível, razão pela qual a este incumbe verificar a oportunidade para obter a medida. Assim, a regra preconizada no art. 273, do CPC harmoniza-se com o princípio dispositivo que, apesar da reformulação por qual passou, continua válido e aplicável ao nosso ordenamento processual, por conta dos arts. $2^{\circ}, 128,333$, entre outros, do CPC.

E finalmente, Zavascki (2005, p. 115) tem a mesma posição que os autores citados acima, para quem a tutela antecipada prevista no art. 273, do CPC dispõe expressamente que a antecipação depende de requerimento da parte, e isso quer dizer que 
ela está sujeita ao princípio dispositivo, o que impede a atuação de ofício do juiz.

O princípio dispositivo, segundo Cintra, Grinover e Dinamarco (2007, p. 70), quer dizer que o juiz fica dependente, na instrução da causa, pela iniciativa das partes na produção probatória e alegações que fundamentará a decisão, tendo a doutrina afirmado que a base para o princípio dispositivo parece ser a necessidade de preservar a imparcialidade do juiz.

Nessa perspectiva, observa-se que a tutela jurisdicional não pode ser prestada de ofício, necessitando de provocação da parte interessada, conforme preconiza o princípio da demanda. E, uma vez ativada a máquina judiciária, as partes podem limitar os fatos e os pedidos deduzidos em juízo, dentro do chamado princípio dispositivo, ficando o órgão jurisdicional na dependência destas, como preservação da imparcialidade do juiz.

Apenas uma observação com relação à iniciativa probatória pode ser referida. Por conta do que dispõe o art. 130, do CPC, há quem entenda que a atuação do juiz em matéria probatória não é limitada pelo princípio dispositivo. Assim, prescreve o art. 130, do CPC “caberá ao juiz, de ofício ou a requerimento da parte, determinar as provas necessárias à instrução do processo, indeferindo as diligências inúteis ou meramente protelatórias".

De fato, pela leitura do referido artigo, verifica-se que a atuação do juiz, em matéria probatória, não é limitada pela iniciativa da parte. Pelo contrário, é admissível dizer que o juiz está em pé de igualdade com as partes na produção de provas. Pode-se dizer que houve uma mitigação do princípio dispositivo no que se refere à produção probatória.

Neste sentido, é o ensinamento de Portanova (2001, p. 122), o qual afirma que a publicização do processo extraiu das partes a possibilidade de limitar a atuação do juiz pertinente a produção probatória, permanecendo, entretanto, a limitação em relação aos fatos e os pedidos. 
Não há dúvida quanto à validade e a plena aplicação do princípio dispositivo no direito processual civil vigente. Contudo, não há violação ao referido princípio na concessão da tutela antecipada de oficio para a doutrina que a autoriza.

Neste sentido, é o entendimento de Pereira Filho (2004, p. 40) quando afirma que não há comprometimento quando o juiz age de oficio em busca da tutela jurisdicional efetiva, só porque as partes tem a disposição para escolherem a prática de determinados atos processuais. $\mathrm{O}$ ordenamento harmoniza-se com princípios opostos como o dispositivo e o inquisitivo. Este admite a atuação de ofício do juiz e aquele admite que a parte escolha quais atos deva praticar.

No mesmo sentido, é o entendimento de Bedaque (2004, p. 807) para quem não há violação ao princípio dispositivo quando o juiz age de ofício, pois o magistrado estará proferindo decisão judicial nos limites do pedido.

Como foi dito acima, o princípio dispositivo visa preservar a imparcialidade do juiz. Isso quer dizer que se o princípio dispositivo for relativizado, a imparcialidade do juiz poderá ficará comprometida. Não é o que pensa a doutrina que admite a concessão de ofício.

Neste sentido, temos Lima (2002, p. 92) asseverando que a imparcialidade não ficará abalada porque o juiz não tomará partido por qualquer uma das partes, apenas agirá para efetivar um direito fundamental. Por essa razão, o direito de ação perde aquele caráter de comando proibitivo ao Poder Legislativo, quando afirma que "a lei não excluirá", para alcançar uma concepção afirmativa que adota o princípio da igualdade e da solidariedade, impondo ao Estado-Juiz o dever de proporcionar adequada e satisfatoriamente a tutela jurisdicional.

Pelo exposto, verifica-se que o princípio dispositivo continua válido e aplicável ao processo civil, não havendo afronta a este, segundo a doutrina que admite a outorga de ofício. E, uma vez movimentado o poder estatal, o juiz deci- 
dirá dentro daquilo que já foi delimitado pelas partes no pedido inicial.

\subsection{A possível violação ao princípio da adstrição do juiz ao pedido}

Outra alegação da doutrina que não admite a concessão de ofício é a violação ao princípio da congruência ou da adstrição do juiz ao pedido. O princípio da adstrição do juiz ao pedido pode ser conferido, por exemplo ${ }^{4}$, no art. 128 do CPC que assim dispõe "o juiz decidirá a lide nos limites em que foi proposta, sendo-lhe defeso conhecer de questões não suscitadas a cujo respeito a lei exige iniciativa da parte" e no art. 460 do CPC que assim prescreve "é defeso ao juiz proferir sentença, a favor do autor, de natureza diversa da pedida, bem como condenar o réu em quantidade superior ou em objeto diverso do que Ihe foi demandado".

Neste sentido, é o entendimento de Didier Jr., Oliveira e Braga (2007, p. 555) quando afirmam que o art. 273, do CPC exige o requerimento expresso da parte, vedando, em conseqüência, a concessão de ofício. A regra exposta harmoniza-se com o princípio da congruência, previsto em nosso CPC nos arts. 128 e 460.

O princípio da congruência ${ }^{5}$ significa, de acordo com Bueno (2008, p. 495), que o juiz só pode decidir e, mais amplamente, agir, de acordo com aquilo que lhe foi pedido.

Para a corrente que admite a concessão de ofício não há violação ao referido princípio, porquanto o juiz decidirá nos limites em que foi pedido.

Neste sentido, Pereira Filho (2004, p. 39) afirma que a concessão de ofício da tutela antecipada não fere o princípio

4 Bueno (2008, p. 496) cita os arts. $2^{\circ}, 128,262,460$, caput, 615, I e 797 do CPC, como outros exemplos de manifestações do referido princípio.

5 Segundo Bueno (2008, p. 495) o princípio da congruência também é conhecido como princípio da vinculação do juiz ao pedido, princípio da imutabilidade do libelo, princípio da adstrição do juiz ao pedido, princípio da correlação entre provimento e demanda. 
da vinculação do juiz ao pedido, porquanto, o juiz não pode transpor os limites do pedido, o que não impede uma atuação de ofício dentro desse parâmetro. A antecipação de tutela não ofende, portanto, nem o princípio da demanda, nem infringe a necessária adstrição do juiz ao pedido.

Por fim, resta verificar a tese da responsabilidade pelos danos eventualmente causados pela execução da medida não confirmada posteriormente.

\subsection{A questão da responsabilidade pelos danos}

Outro argumento da doutrina que não admite a concessão da tutela antecipada de ofício é que na execução da tutela antecipada, eventuais danos serão suportados pela parte que nada requereu, assim como ocorre na tutela cautelar. Assim, apenas a parte deveria avaliar se quer ou não correr o risco de requerer a tutela antecipada.

Neste sentido, é o entendimento de Carreira Alvim (2006, p. 38) quando afirma que o juiz não poderia adiantar ao autor o que não foi pedido, tendo em vista que a efetivação de uma medida antecipada provoca a responsabilidade objetiva daquele que a executou, o qual deve, no caso da sentença modificar ou revogar a decisão interlocutória, restabelecer as partes ao estado anterior (art. 273, §3, c/c o art. 475-O, II, ambos do CPC).

É que a efetivação da tutela antecipada, conforme dispõe o $\$ 3^{\circ}$, do art. 273, do CPC, observará, no que couber e conforme sua natureza, as normas previstas nos $461, \S \S 4^{\circ}$ e $5^{\circ}$, e $461-A$ do CPC.

A responsabilidade pelo manejo indevido da tutela antecipada é enfrentada por Lopes (2007, p. 152) quando afirma que na hipótese do réu vir a sofrer dano com a antecipação postulada, o autor deverá responder objetivamente, não se aceitando o argumento de que os danos não decorreram de ato do autor, mas da decisão judicial, razão pela qual a responsabilidade seria do Estado. 
Em que pese às ponderações acima, entende Pereira Filho (2004, p. 49) que a responsabilidade pela revogação da medida não é empecilho para a concessão de ofício do adiantamento antecipado, pois é indubitável que os prejuízos ocasionados a outra parte, poderão ser suportados por quem, eventualmente, os ocasionou. Entretanto, quem comparece em juízo tem ciência que a prestação da tutela jurisdicional poderá ser prestada em favor de um ou de outro litigante.

Albuquerque (2000, p. 58) faz uma comparação quanto à reparação dos danos incidentes na concessão de ofício da tutela antecipada com a prisão irregular, afirmando que a questão dos danos é respeitável, mas não ao ponto de se denegar uma tutela jurisdicional efetiva a quem precise. Se a preocupação da doutrina gira em torno dos danos, que inicie seus debates pela prática processual penal. A prisão processual, embora chamada de cautelar, nada mais é do que uma antecipação dos efeitos de eventual condenação. E esta sim tem muito mais aptidão para acarretar um dano sem volta à vida de um inocente.

Enfim, a tutela antecipada concedida no início do processo poderá não ser confirmada ao final. E isso, poderá gerar danos para a parte contrária, visto que a efetivação da tutela antecipada se dá nos moldes do $\$ 3^{\circ}$, do art. 273, do CPC. E esses danos deverão ser indenizados pela parte que dela se beneficiou. Por isso, o conflito entre as correntes doutrinárias, visto que haverá sempre um risco a ser enfrentado, seja no instante em que se ajuíza uma ação ou na formulação de um requerimento de antecipação de tutela.

\section{OUTRAS CONSIDERAÇÕES ACERCA DA CONCESSÃODEOFÍCIODATUTELAANTECIPADA}

Feitas todas essas ponderações acerca dos argumentos favoráveis ou não para a outorga de ofício da tutela antecipada, é oportuno colacionar a irresignação feita pelo doutrinador Fux acerca da ausência de autorização legal expressa para o juiz 
conceder a tutela antecipada de ofício, perdendo o legislador, com isso, a oportunidade de modificar com audácia o princípio da inércia jurisdicional.

Segundo explica Fux (2005, p. 57), a idéia de segurança impediu o legislador de vislumbrar que há casos notórios de defesa da própria jurisdição, a qual não pode ficar a mercê do pedido dos litigantes. A atuação de ofício é conseqüência do dever geral de segurança nos quais se apóia os poderes instrumentais do juiz para prestar a atividade jurisdicional.

É interessante ainda trazer à colação a solução intermediária dada por alguns doutrinadores, embora tenham ciência de que a concessão da tutela antecipada depende de requerimento, admitem que em certos casos, a melhor opção é a concessão de ofício.

É o caso de Nery Jr. e Rosa Nery (2002, p.613) lecionando que quando se trata de reclamação trabalhista de empregado que não esteja representado por advogado, admite-se a concessão ex officio da tutela antecipada, tendo em vista o cunho social do processo trabalhista e a condição de não estar representado por profissional especialista na área.

Numa outra situação mediana, manifesta-se Bueno (2004, p. 33) afirmando que pela letra da lei, a concessão de ofício é inadmissível, porém, numa visão constitucionalista do processo, parece que a resposta é positiva. Se o advogado é despreparado ou desatinado e não fez o requerimento de antecipação de tutela, não é por isso que o juiz estará impedido de realizar o valor "efetividade", mormente quando verificar a presença dos demais pressupostos para a concessão, sobretudo nos casos do art. 273, I, do CPC. E, se não for o caso de urgência, seria o caso do juiz determinar a emenda da inicial, dando uma ampla interpretação ao art. 284, do CPC.

Aqueles que não admitem a concessão de ofício da tutela antecipada, além do suporte previsto no próprio art. 273 , do $\mathrm{CPC}$, que exige o requerimento da parte, ancoram o seu enten- 
dimento nos princípios inerentes ao processo civil, como o dispositivo, a demanda, a adstrição do juiz ao pedido, além da própria responsabilidade advinda pelo manejo indevido de uma antecipação de tutela não solicitada.

Por outro lado, os adeptos da concessão de ofício da tutela antecipada embasam o seu entendimento, entre outros argumentos, no direito fundamental a uma tutela efetiva. Isso porque o acesso ao judiciário, previsto no art. 5, XXXV, da CF não garante apenas o direito de propor uma ação. É mais do que isso, é a garantia de um direito a uma tutela efetiva.

\section{CONClUSÃo}

O presente estudo averiguou a possibilidade do magistrado conceder a tutela antecipada de ofício, prevista no art. 273 do CPC, sem o requerimento expresso da parte.

Foi possível constatar que os requisitos para a concessão da tutela antecipada constam no art. 273 do CPC. Este dispositivo legal permite que o juiz antecipe, total ou parcialmente, os efeitos da tutela pretendida, se a parte o requerer, desde que exista prova inequívoca idônea para convencer o magistrado da verossimilhança da alegação. Tais requisitos devem estar sempre presentes para a pretendida concessão.

Assim, examinada a natureza jurídica e os pressupostos legais da tutela antecipada, passamos a verificar a possibilidade de sua outorga sem o requerimento expresso do interessado. Para isso, chamamos a atenção para o estudo da CF como norteador dos princípios e garantias fundamentais do processo.

Constatou-se que a ordem constitucional se preocupa em proteger o processo, assegurando-o de garantias e princípios, dos quais não se pode afastar nem o legislador infraconstitucional quando da elaboração das leis processuais, nem o operador jurídico quando da interpretação da lei.

As normas jurídicas dividem-se em princípios e regras e, tendo em vista que o instituto da tutela antecipada, além do 
regime legal, é regulada também sob o prisma constitucional, verificou-se a necessidade de diferenciar as regras dos princípios.

Enquanto as regras procuram regular uma situação específica, os princípios representam modelos de justiça. E quando há uma situação de colisão entre os princípios, não haverá uma revogação entre eles, porque isso é fato que só ocorre com as regras. A solução, então, será a prevalência de um princípio sobre o outro, daquele que tem peso maior sobre o que tem peso menor.

Assim, apurou-se que a interpretação da Constituição deve ser feita sistematicamente, garantindo-se a exegese que assegure a máxima efetividade diante de um conflito entre princípios constitucionais, para manter a sobrevivência de ambos os valores postos em debate. Isso tudo, mediante o uso da proporcionalidade.

No caso da tutela antecipada, dois princípios constitucionais ou direitos fundamentais são colocados em tensão: o da efetividade da tutela jurisdicional (art. 5 XXV, da CF) e o da segurança jurídica (art. 5, LIV e LV, da CF). Como os dois princípios derivam diretamente do texto constitucional não se pode falar em hierarquia entre eles.

A efetividade deve servir de orientação na condução do processo, cuidando, evidentemente, para não ferir outros valores previstos constitucionalmente, a fim de garantir a presença de um processo justo. Já o princípio da segurança jurídica pode ser conferido no inciso LIV, do art. 5o da CF, quando fala do devido processo legal, e como desdobramento, no inciso LV, do mesmo artigo, quando fala do contraditório e da ampla defesa.

A tutela antecipada faz prevalecer o princípio da efetividade sobre o princípio da segurança, entretanto, não há um aniquilamento de um princípio sobre outro. Ocorre que o princípio do contraditório será observado, porém, ficará diferido para momento posterior do processo.

Por fim, delimitada a base constitucional, foi iniciado o estudo acerca da possibilidade de concessão da tutela antecipada sem o requerimento da parte, apurando-se que, algumas fundamentações para aqueles que não admitem a concessão de 
ofício, embasam o seu entendimento no princípio da demanda, no princípio dispositivo, no princípio da adstrição do juiz ao pedido, além da questão da responsabilidade do juiz.

O princípio da demanda informa que o juiz não pode instaurar de ofício a relação processual, cabendo às partes, se assim o desejarem, levar a lide ao Poder Judiciário para que este, em substituição, os solucione. Já o princípio dispositivo delimita a atuação do juiz em relação aos fatos e aos pedidos que fundamentará a decisão, servindo inclusive como forma de preservar a imparcialidade do juiz. E, por fim, o princípio da adstrição do juiz ao pedido informa que aquele só poderá decidir e, mais amplamente, agir, de acordo com aquilo que lhe foi pedido, nem mais, nem menos ou, tampouco, fora do que lhe foi requerido.

Porém, segundo a doutrina que admite a atuação de ofício, nenhum dos princípios é violado. Uma vez provocada a manifestação do Poder Judiciário pelo interessado e, respeitados todos os requisitos legais para o ajuizamento de uma ação, o processo se movimenta por impulso oficial, portanto, não há afronta ao princípio da demanda. Da mesma forma, quanto ao princípio dispositivo, no instante em que se movimenta a máquina judiciária, o juiz decidirá dentro daquilo que já foi delimitado pela parte no pedido inicial. E por fim, não há que se falar em ofensa ao princípio da vinculação do juiz ao pedido, porquanto, aquele não poderá transpor os limites do pedido.

E a alegação de responsabilidade pelos danos advindos pela execução da medida antecipada não deve servir como óbice à concessão de ofício, segundo a corrente que admite a outorga de ofício da tutela antecipada. Isso porque aquele que comparece em juízo tem ciência de que a prestação da tutela jurisdicional poderá ser prestada em favor de um ou de outro litigante.

Em que pese à grande quantidade de doutrinadores manifestando-se contrariamente a concessão da tutela antecipada de ofício, o que parece ser a maioria, deve-se dizer que o acanhado número de operadores do Direito que admitem a possibilidade, possuem mais argumento jurídico do que aqueles. Pela 
pesquisa, alguns doutrinadores não admitem a concessão de ofício e ponto final sem maiores explicações, indicando o dispositivo legal, cingindo-se apenas a uma interpretação literal.

E é interessante notar que, mesmo aqueles que não aceitam a concessão de ofício, admitem em determinadas situações, como no processo trabalhista, por exemplo. E há ainda quem indique uma solução intermediária, no caso em que a urgência não se mostrar evidenciada, sugerindo que o juiz determine a emenda da inicial.

Abstract: This paper examines the possibility of the magistrate to grant the injunction of office as provided for in art. 273 of the Code of Civil Procedure, without the express request of a party. Notes such Office, with the legal concept, the fundamentals and the possible collision of fundamental rights or principles for the grant. Investigates the doctrinal underpinnings of the current that admits and acknowledges that not granting their craft early advance in order to express provision in art. 273 of the Code of Civil Procedure, requiring the "application of an interested party" for the granting of anticipatory measure.

Keywords: Injunctive Relief. Granting of Injunctive Relief for Office. Effectiveness.

\section{REFERÊNCIAS}

ALBUQUERQUE, Bruna Maria Jacques Freire de. A efetividade do processo, o contraditório e a ampla defesa: conciliação dos princípios nas ações cautelares. Revista ESMAFE-5a, Recife, n.3, p. 235-277, mar. 2002.

ALBUQUERQUE, Luciano Campos de. A possibilidade da concessão de tutela antecipada sem requerimento expresso da parte. Julgados do Tribunal de Alçada do Paraná, Curitiba, Juruá, vol. 11, jan. 2000, p. 35-60.

ALEIXO, Pedro Scherer de Mello. O direito fundamental à tutela jurisdicional efetiva na ordem jurídica brasileira: a caminho de um efetivo processo proporcional. In: MONTEIRO, Antonio Pinho; NEURER, Jörg; 
SARLET, Ingo (Org.). Direitos fundamentais e direito privado: uma perspectiva de direito comparado. Coimbra: Almedina, 2007, p. 417-435.

ALEXY, Robert. Colisão de direitos fundamentais e realização de direitos fundamentais no estado de direito democrático. Revista de Direito Administrativo, Rio de Janeiro, v. 217, p. 67-79, jul./set. 1999.

ALVIM, Luciana Gontijo Carreira Alvim. Tutela antecipada na sentença: com as alterações no CPC, pelas Leis n. 10.352/01 e 10.444/02, e de acordo com o Novo Código Civil - Lei n. 10.406/02. Rio de Janeiro: Forense, 2003.

BEDAQUE, José Roberto dos Santos. Direito e Processo: influência do direito material sobre o processo. 2 ed. São Paulo: Malheiros, 2001.

José Roberto dos Santos. Comentários aos arts. 272 e 273. In:

MARCATO, Antonio Carlos (Coord.). CPC Interpretado. São Paulo: Atlas, 2004, p. 788-813.

BUENO, Cassio Scarpinella. Tutela Antecipada. São Paulo: Saraiva, 2004.

, Cassio Scarpinella. Curso Sistematizado de Direito Processual Civil: teoria geral do direito processual civil 1.2 ed. rev. atual e ampl., São Paulo: Saraiva, 2008.

BRUSCHI, Gilberto Gomes. A tutela antecipada e a postura do juiz diante do pedido liminar: a possibilidade de sua concessão antes da citação do réu visando maior efetividade ao processo. In: MEDINA, José Miguel Garcia et al. (Coord). Os poderes do juiz e o controle das decisões judiciais: estudos em homenagem à professora Teresa Arruda Alvim Wambier. São Paulo: Revista dos Tribunais, 2008, p. 424-441.

CAVALCANTE, Márcio André Lopes. A relativização da coisa julgada inconstitucional segundo critérios objetivos. In: OLIVEIRA, Vallisney de Souza (Coord.). Constituição e Processo Civil. São Paulo: Saraiva, 2008, p. 145-193.

CARREIRA ALVIM, José Eduardo. Tutela antecipada. 5 ed. rev. e atual. por Luciana Gontijo Carreira Alvim Cabral. Curitiba: Juruá, 2006.

CINTRA, Antônio Carlos de Araújo; GRINOVER, Ada Pellegrini; DINAMARCO, Cândido Rangel. Teoria Geral do Processo. 23 ed. São Paulo: Malheiros, 2007.

DIAS, Beatriz Catarina. A jurisdição na tutela antecipada. São Paulo: Saraiva, 1999.

DIAS, Handel Martins. O tempo e o processo. Revista da Ajuris, Porto Alegre, ano XXXIV, n.108, p. 227-245, dez. 2007. 
DIDIER Jr. Freddie; OLIVEIRA, Rafael; BRAGA, Paula Sarno. Curso de Direito Processual Civil: vol. 2. Salvador: Podivm, 2007.

DINAMARCO, Cândido Rangel. A instrumentalidade do processo. 13. ed. São Paulo: Malheiros, 2008.

\section{, Cândido Rangel. A reforma do Código de Processo de Processo}

Civil: (Leis n. 8.455, de 24.8.92; 8.637, de 31.3.93; 8.710, de 24.9.93; 8.718, de 14.10.93; 8.898, de 29.6.94; 8.950, de 13.12.94; 8.951, de 13.12.94; 8.952, de 13.12.94; 8.953, de 13.12.94; 9.079, de 14.7.95; 9.139, de 30.11.95; 9.245, de 26.12.95). 5 ed. rev. ampl. e atual. São Paulo: Malheiros, 2001.

FIGUEIRA JR., Joel Dias. Comentários ao CPC: vol 4, tomo I, do processo de conhecimento arts. 270 a 281. 2 ed. rev., atual. e ampl.. São Paulo: Editora Revista dos Tribunais, 2007.

FUX, Luiz. Curso de Direito Processual Civil: vol. 1, 3 ed. Rio de Janeiro: Forense, 2005.

LIMA, George Marmelstein Lima. Antecipação da tutela de ofício? Revista CEJ -Centro de Estudos Judiciários do Conselho da Justiça Federal, ano VI, n.19, p. 90-93, out./dez/2002.

LOPES, João Batista. Efetividade da tutela jurisdicional à luz da constitucionalização do processo civil. Revista de Processo, São Paulo, ano 29, n. 116, p. 29-39, jul-ago/2004.

, João Batista. Tutela antecipada no processo civil brasileiro. São Paulo: Editora Revista dos Tribunais, 2007.

MACHADO, Antonio Cláudio da Costa. Tutela antecipada. São Paulo: Oliveira Mendes, 1998.

MARINONI, Luiz Guilherme. Tutela antecipada e julgamento antecipado: parte incontroversa da demanda. 5 ed. rev., atual e ampl. da obra tutela antecipatória, julgamento antecipado e execução imediata da sentença. São Paulo: Revista dos Tribunais, 2002.

, Luiz Guilherme. Antecipação da tutela. 9 ed. rev. atual. e ampl. São Paulo: Editora Revista dos Tribunais, 2006.

MEDINA, Paulo Roberto de Gouvêa Medina. Direito Processual

Constitucional. 3 ed. rev. ampl. e atual., inclusive de acordo com a Emenda Constitucional n. 45/2004. Rio de Janeiro: Forense, 2005. 
NERY JUNIOR, Nelson; NERY, Rosa Maria de Andrade. CPC comentado e legislação processual civil extravagante em vigor: atualizado até 15.03.2002. 6 ed. rev.. São Paulo: Revista dos Tribunais, 2002.

OLIVEIRA, Bruno Silveira de. Os princípios constitucionais, a instrumentalidade do processo e a técnica processual. Revista de Processo, São Paulo, ano 32, n. 146, p. 321-331, abr. 2007.

OLIVEIRA, Vallisney de Souza. O direito à razoável duração do processo após a emenda constitucional n. 45/2004. In: OLIVEIRA, Vallisney de Souza (Coord.). Constituição e Processo Civil. São Paulo: Saraiva, 2008, p. 2-37.

ORIONE NETO, Luiz. Liminares no processo civil e legislação processual civil extravagante. 2 ed. São Paulo: Método, 2002.

PASSOS, José Joaquim Calmon de. Comentários ao CPC: vol.3 (arts. 270 a 331). 2 ed. rev. e atual. (inclusive de acordo com o Novo Código Civil). Rio de Janeiro: Forense, 2004.

PEREIRA FILHO. Benedito. Tutela antecipada: concessão de ofício? Revista da Ajuris, Porto Alegre, vol. 95, p. 37-53, set. 2004.

PORTANOVA, Ivo. Princípios do processo civil. 4 ed. Porto Alegre: Livraria do Advogado, 2001.

RODRIGUES, Marcelo Abelha. Manual de Direito Processual Civil. 4 ed. Reformulada, atualizada e ampliada da obra Elementos de Direito Processual Civil. São Paulo: Revista dos Tribunais, 2008.

SILVA, Ovídio Araújo Baptista da. Curso de Processo Civil: vol. 2, processo cautelar (tutela de urgência). 4 ed. rev. e ampl..Rio de Janeiro: Forense, 2007.

VAZ, Paulo Afonso Brum. Manual da Tutela Antecipada: doutrina e jurisprudência. Porto Alegre: Livraria do Advogado, 2002.

WAMBIER, Luiz Rodrigues (Coord); ALMEIDA, Flávio Renato Correia de; TALAMINI, Eduardo. Curso Avançado de Processo Civil, vol. 01: teoria geral do processo de conhecimento. 7 ed. rev. e atual.. São Paulo: Editora Revista dos Tribunais, 2005.

WATANABE, Kazuo. Tutela antecipatória e tutela específica das obrigações de fazer e não fazer - arts. 273 e 461 do CPC. Revista de Direito do Consumidor, São Paulo, n.19, 1996, p. 77-101, jul/set. de 1996.

ZAVASCKI, Teori Albino. Antecipação da Tutela. 4 ed. rev.e ampl.. São Paulo: Saraiva, 2005 